\title{
Supply Chain Fair Profit Allocation Based on Risk and Value Added for Sugarcane Agro-industry
}

\author{
Muhammad Asrol* \\ Department of Agro-industrial Technology, Faculty of Agricultural Engineering and Technology \\ University (Bogor Agricultural University), Bogor, Indonesia \\ Email: muhammadasrolnaa@gmail.com (Corresponding Author)
}
Marimin
Department of Agro-industrial Technology, Faculty of Agricultural Engineering and Technology
University (Bogor Agricultural University), Bogor, Indonesia
Email: marimin@ipb.ac.id

\begin{abstract}
Machfud
Department of Agro-industrial Technology, Faculty of Agricultural Engineering and Technology University (Bogor Agricultural University), Bogor, Indonesia
\end{abstract}

\begin{abstract}
Moh. Yani
Department of Agro-industrial Technology, Faculty of Agricultural Engineering and Technology

University (Bogor Agricultural University), Bogor, Indonesia
\end{abstract}

\author{
Eizo Taira \\ Faculty of Agriculture \\ University of the Ryukyus, Nishihara, Okinawa, Japan
}

\begin{abstract}
Profit allocation is the main critical problem in the supply chain. In agro-industry supply chain, establishing a fair and reasonable profit allocation has been more challenging due to the influence of uncertain factors. Cooperative game theory with the Shapley value has an opportunity to solve this problem given its appropriateness for the key goals of the supply chain. Fuzzy Shapley value was developed to accommodate uncertain stakeholders' payoff. In addition, uncertain risk and value added were considered for a reasonable profit allocation. This model succeeded in a case study of finding a fair profit allocation in the sugarcane agro-industry supply chain taking into account uncertain risk and value added. The model validation showed that sugarcane farmers, mills, and distributors achieved $35.38 \%, 30.11 \%$, and $34.51 \%$ of profit share, respectively. Stakeholders achieved their profit share based on their marginal contribution, risk potential, and valueadded contribution, which may increase supply chain stability.
\end{abstract}

Keywords: fuzzy shapley value, game theory, profit allocation, sugarcane, supply chain

\section{INTRODUCTION}

Supply chain is a network of business processes that involve stakeholders with different goals and bargaining power to do coordination for maximizing profit while maintaining competitive advantage. To maximize profit, supply chain generates value for consumers through specific processes by each stakeholder. Supply chain stakeholders have their particular activities, manage their risks, and coordinate upstream and downstream supply chain to achieve its goals. Therefore, a local weakness and risk of a stakeholder may become a major problem in supply chains that affects performance (Omri, 2009; Wang et al., 2016). Thus, the main concept of supply chain entails cooperation among stakeholders to realize a greater profit (Alahmari et al., 2017).

Challenges in the agro-industry supply chain have been more complicated due to certain constraints in the behavior of raw material (Chopra and Sodhi, 2004). This behavior involves multiple stakeholders and sectors, and contains high levels of risk and volatility in profits as influenced by uncertain factors (Kumari et al., 2014). As for instance, total profit in the supply chain may not be allocated fairly to all stakeholders (Liu and Papageorgiou, 2018). This phenomenon is common in the agro-industry supply chain. Thus, profit allocation is the main issue in supply chain cooperation that should be resolved accordingly ( $\mathrm{Yu}$ and Zhang, 2010; Liu and Sui, 2016; An et al., 2018).

Profit in the agro-industry supply chain should be allocated reasonably and fairly to motivate stakeholder cooperation and thus avoid internal conflict (Gao et al., 2017; An et al., 2018). With a fair profit allocation, stakeholders receive fair returns for contributions in the supply chain alliance. Evidently, fair allocation of profit among supply chain stakeholders is challenging due to many uncertain factors that should be considered (Chen et al.,

\footnotetext{
${ }^{*}$ The first author is also with Master in Industrial Engineering - Binus Graduate Program, Binus University, Indonesia
} 
2010). This paper will discuss two uncertain contributions and performances of stakeholders to the agro-industry supply chain alliance, namely, risk and value added. Supply chain risk is commonly faced by all stakeholders in different dimensions and quantities, which make inefficient valueadded creation by stakeholders (Wang et al., 2013). Therefore, due to their behavior, risk and value added should be considered in establishing a fair profit allocation.

As aforementioned, the key concept of supply chain involves cooperation among stakeholders. Therefore, establishing a fair profit allocation for the supply chain allows cooperative game theory to mitigate the issue in profit allocation. Cooperative game theory mainly aims to provide reasonable payoff to cooperating stakeholders. Moreover, a long-term guarantee and stable stakeholder cooperation help mitigate the contradictory problem (Sana et al., 2017; Huang et al., 2018) and meet the goals of the supply chain. Additionally, although game theory in supply chain lacks application (Cachon and Netessine, 2006; Ren et al., 2015), it provides an effective solution to profit allocation.

The Shapley value is often applied as an effective method in cooperative game theory that solves conflict and profit allocation (Castro et al., 2017). The Shapley value was proposed by Shapley (1953) to allocate profit among agents in a coalition based on their contribution to the games with crisp coalitions. Although the classical Shapley value may perform well in allocating profit among agro-industry stakeholders fairly (Thun, 2008), it has limitations that need amendments to adjust to our case. To the best of our knowledge, no scholars had considered risk and value added in profit allocation in the agro-industrial supply chain. Similarly, considering only an average marginal contribution for developing a fair and balanced profit allocation would be insufficient (Wang et al., 2014; Alahmari et al., 2017). Thus, we will consider risk and value added in the present study.

The objective of this study is to provide a fair profit allocation based on stakeholders' uncertain risks and value added in the agro-industry supply chain. We consider risk and value added in profit allocation due to their conflicting nature that needs appropriate measurement to guarantee a long-term and stable supply chain. The classical Shapley value will be modified to solve uncertain problems in the agro-industry supply chain. For validation, we apply sugarcane agro-industry supply chain as a case study.

\section{LITERATURE REVIEW}

\subsection{Supply Chain Management}

Supply chain is defined as a group of companies that have different phases in the production process and thus connect and interact to add value to their products to satisfy consumer demand. Chopra and Meindl (2013) stated the supply chain involve various activities not only in the manufacture and supply products and raw materials but also in transportation, inventory and marketing as well as those of the consumers. The supply chain is a solution concept proposed by scholars to maximize profit through stakeholder cooperation. Thus, an effective management is required for stakeholder cooperation and coordination of activities in the supply chain.

Supply chain management aims to maximize the value added of products for consumer satisfaction, efficient stakeholder coordination, and maximized profit of coalitions
(Kohli and Jensen, 2010). Supply chain management was developed when optimum logistics and physical distribution were needed in the mid-1960s. According to Ballou (2007) and Monczka et al., (2016), supply chain management comprises material and supply management, physical distribution, strategic planning, information services, marketing, and finance to meet stakeholders' current and future needs and thus achieve their goals. Furthermore, due to the complexity of the supply chain that involves multiple stakeholders, information system, decision making, and profit allocation, exploring it extensively is crucial for understanding.

Research on supply chain management has grown extensively as the demand for practical issues in the industry increases. Many scholars proposed supply chain collaboration among stakeholders to improve performance, share information to maintain coordination, share risk and profit, and construct a decision-making system for the development of a sustainable and efficient supply chain (Ronchi et al., 2007; Ralston, 2014; deSouza and Haddud, 2017). Collaboration in supply chain has been challenging as it involved multiple actors and sectors that performed different activities and faced various risks. Stakeholders in supply chain management have different goals that may give rise to conflicts, which require appropriate and achievable solution. Stakeholders' main goal in joining the supply chain alliance is to maximize their profit. Hence, profit distribution in the supply chain needs to be explored. LV and QI, (2016) stated that certain factors that need to be considered in profit allocation in supply chain include fair profit, risk compensation, investment value, equity, and efficiency.

\subsection{Agro-industry Supply Chain Management}

Agro-industry is defined as a sequence business activity aimed at increasing value-added of agricultural products by transforming them chemically or physically. Agro-industry comprises upstream and downstream stakeholders that allow the production of high value products. This process needs collaboration with farmers as suppliers of raw materials, factories as processors, and distributors that deliver the products to the consumers. Stakeholder coordination in agroindustry needs appropriate supply chain management. That is, agro-industrial supply chain involves farmers, factories, and distributors to supply raw materials, add value to these materials through a complex process, and deliver the final product to the consumers, respectively.

Agro-industrial supply chain management faces more complex and massive problems than the manufacturing industry. For example, Van der Vorst and Snels (2014) emphasized that in agro-industrial supply chain, decisionmakers must deal with the challenging nature of agricultural commodities such as seasonal and bulk production, climate change sensitivity, and holding product quality to develop marketing strategy and thus meet consumer demand. In addition, the agro-industrial supply chain problem also involves uneven profit distribution among its stakeholders.

As stated by Starks and Bukenya (2008), only a few stakeholders gain profit in the agro-industrial supply chain due to their great bargaining power. This condition would interrupt the stability of the supply chain, and stakeholders may lose enthusiasm to cooperate. Many scholars found unfair profit allocations in the agro-industrial supply chain of products, such as corn (Suharjito and Marimin, 2012), palm 
oil (Hidayat, 2012), dairy (Qian et al., 2013), cocoa (Sana et al., 2017), and coffee (Fadhil et al., 2018). Additionally, based on our previous research on the agro-industrial supply chain of sugarcane, we found that upstream stakeholders bear major risks, whereas downstream stakeholders benefit major value added and profit (Asrol, 2019).

\subsection{Supply Chain Risk and Value Added}

Risk in supply chain is referred to as uncertain events that negatively affect one or all stakeholders, which may result in failure of achieving the supply chain goals (Astuti et al., 2013). This risk can be minimized through risk management that involves identification, assessment, and mitigation. All phases in the supply chain are interconnected and thus affect each other. Therefore, all stakeholders should be identified with their corresponding risk. Risks are measured through risk probability and risk consequence and impact to the supply chain (Hudnurkar et al., 2017). Risk mitigation focuses on risk priority based on risk measurement, which is significant in reducing loss in the supply chain during the production process (Enyinda, 2018). Additionally, risk sharing can also mitigate risk in the supply chain reasonably for all stakeholders as a correction factor for the profit proposed by the model in this research.

The supply chain aims to deliver high value for consumers and generate profits. Stakeholders in supply chain have to coordinate and collaborate to maintain the value added of a product, for which consumers are willing to pay (Trienekens, 2011). Value added creation of a product in a supply chain is the real contribution of stakeholders to supply chain. Therefore, value added should be identified in each phase and with each stakeholder in supply chain. In this research, we restricted the definition of value added according to Ricketts et al. (2014) and Deng et al. (2016) as an increasing value of a product through the addition of a specific input, process, and treatment of raw materials by the stakeholders in the supply chain.

\subsection{Cooperative Game Theory: The Shapley Value and Its Limitations}

Game theory is a strategic quantitative method for decision making in conflict resolution and stakeholder cooperation. Given its optimal function and solution, game theory has been applied in various fields, such as computer science, logistics, business, and social science. Based on the nature of negotiation behavior, Wang and Parlar (1989) classified game theory into non-cooperative and cooperative games. On the one hand, players in a non-cooperative game act and make decisions individually to maintain the best response to the games and thus maximize their profit (AbedElmdoust and Kerachian, 2012; Borkotokey and Mesiar, 2014). Players in a cooperative game develop coalitions to maximize group payoff and share it with the games' other agents. Moreover, players in non-cooperative games focus on how to define strategy by predicting another agent's strategies to win in the competition, whereas players in cooperative games focus on coordination to gain stable stakeholder payoff (Omri, 2009; Le, 2017).

Our supply chain management in this present study is relevant to a cooperative game's environment because players coordinate with each other to maximize global profit (Cachon and Netessine, 2006; Thun, 2008; Sana et al., 2017). Cooperative game theory focuses on coordination to maximize group payoff. Therefore, a new problem arises on how to share the profit for all game players in the coalition. The basic assumption in cooperative game should be noted, that is, by winning in the competition and sharing the benefit among game players with respect to an agreement, this problem is solved (Mares, 2001). The assumption of sharable profit/utility among players is also popular in transferable utility games (TUG) (Nishizaki and Sakawa, 2001).

One of the most strategic methods in cooperative games that consider players' interaction and contribution to the game is the Shapley value (Borkotokey and Mesiar, 2014). As introduced by Shapley (1953), the Shapley value is a method of establishing a fair and reasonable payoff allocation among players in cooperative games. The Shapley value is characterized by TUG environment, finite players, real-number payoff, and single solution. The Shapley value has been widely applied in many cases due to its performance in solving risk and reward sharing (Alparslan Gök et al., 2010). The basic allocation principle of the Shapley value is to ensure fairness by sharing the profit gained by the coalition among all players with respect to their marginal contribution to the coalition (Wu, 2010).

Although the Shapley value is an effective and powerful method of distributing profits to all members of the coalition, it has certain weaknesses that requires modifications for applying in supply chain. Weaknesses of the Shapley value have been stated by previous authors. As aforementioned, the Shapley value distributes payoff based on the player's marginal contribution to the coalition. However, various uncertainty factors med to be considered to define fair payoff and profit sharing (Alahmari et al., 2017; Hu and Feng, 2017). The most important considerations that should be applied to modify the Shapley value in supply chain are the players' risk, contribution and input to the supply chain coalition (Xu et al., 2014; Yang et al., 2017). Gao and Shi (2010) and Xu et al. (2018) stated that the Shapley value assumes that the players in a coalition have identical risks and must face different risk occurrences and severities to gain profit and provide contribution to the coalition. On the contrary, value added also has high contribution that reflects supply chain stakeholders' performance. Highest value-added gained aims to achieve appropriate profit allocations. Risk and value added are conflict factors in establishing fair profit allocation in supply chain and thus studied to address the issue.

Sana et al. (2017) stated that the limitation of the Shapley value, which was applied in agro-industrial supply chain, is the deterministic parameters of value definition. The Shapley value assumes that players are aware of their profit before joining a coalition. Moreover, it is not appropriate to imprecise and blurred information of coalition outcomes, which is found in the real-world case (Borkotokey, 2008; Abed-Elmdoust and Kerachian, 2012). Coalition in classical Shapley value has been defined by many scholars before in a set of real numbers (Borkotokey, 2008; Meng et al., 2016). This definition did not reflect the real supply chain situation, though with imprecise and uncertain information. In this situation, fuzzy set theory can answer this challenge to deal with incomplete information in few applications (Jian-gang and Guang-dong, 2009; Gao et al., 2011). Therefore, in addition to considering risk and value-added contribution for supply chain profit allocation, supply chain payoff in uncertain and fuzzy parameter value is also defined. 


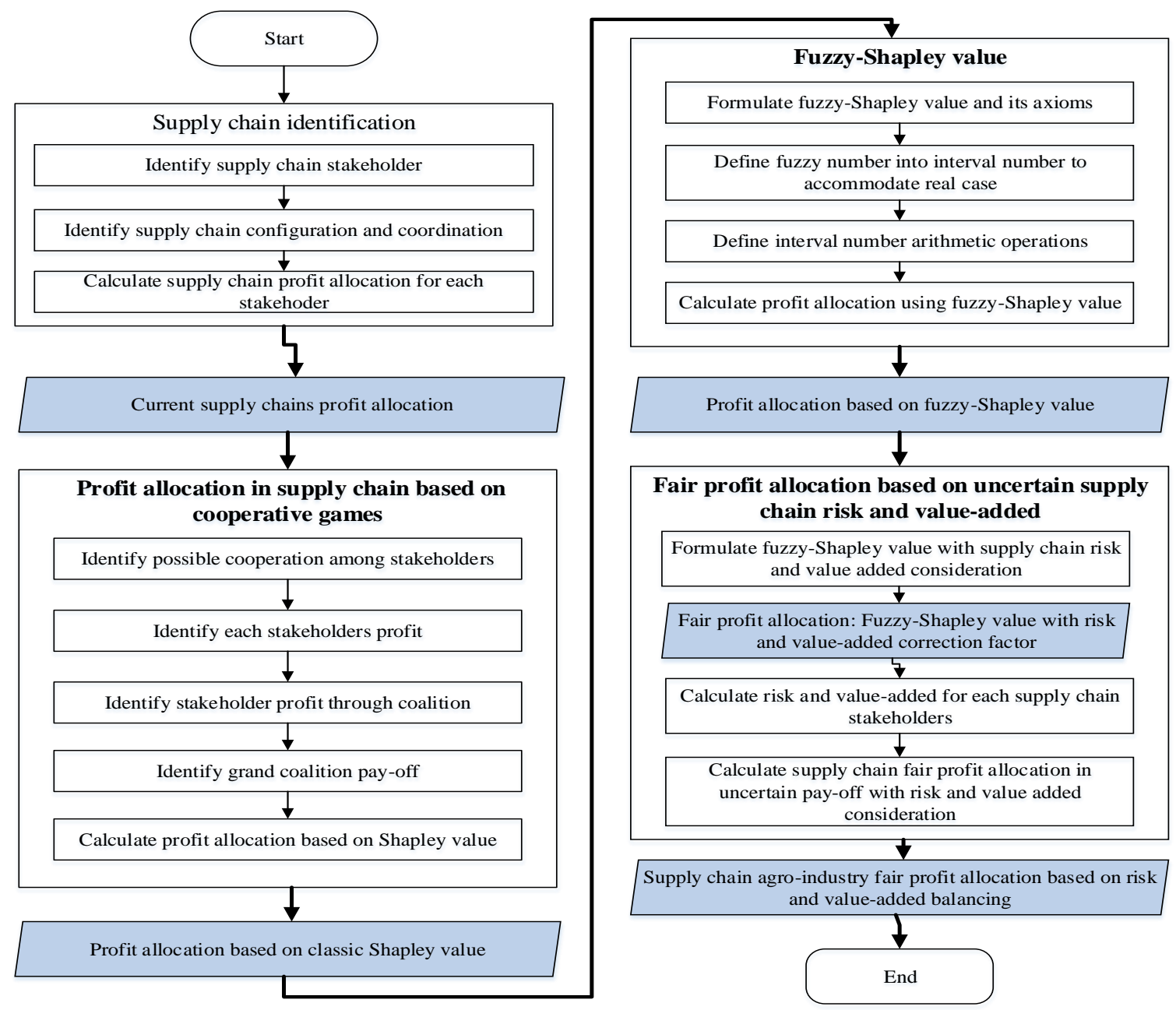

Figure 1 Research Network

\section{RESEARCH METHODOLOGY}

\subsection{Research Framework and Data Acquisitions}

Figure 1 shows the research framework of this study. Four main problems and ideas in supply chain management as stated at the previous sections are found, namely, uncertain cooperative agro-industrial supply chain management, fair profit allocation in supply chain, capabilities and limitations of cooperative game theory, and the Shapley value for solving fair profit allocation in agroindustrial supply chains. Therefore, a cooperative game theory and its modifications are needed to solve uncertain fair profit allocation for sugarcane agro-industry.

Sugarcane agro-industrial supply chain is selected in this study to investigate its mechanism and profit sharing and thus evaluate the current situation of profit allocation in the real world. This research aims to define a profit allocation model among supply chain stakeholders by balancing risk and value added. In the first stage, the classic Shapley value model is implemented to distribute profit in the sugarcane supply chain. In this phase, profit allocation is established based on the classic Shapley value model and its limitations. To accommodate the study objective, the classic Shapley value is applied to develop a reasonable profit allocation model among stakeholders.
This paper proposed and formulated the fuzzy Shapley value to deal with the uncertain environment in the agroindustrial supply chain while meeting the Shapley axioms and following fuzzy set theory. The first phase has determined that risk and value added need to be considered to for fair profit allocation. Furthermore, balance between uncertain risk and value added is also considered to amend profit allocation. The model is proposed to establish a reasonable profit distribution among sugarcane supply chain stakeholders.

Data in this research are obtained through (1) field observation, (2) agro-industrial data documentation acquisition, (3) expert survey and questionnaire, and (4) literature review. This research was conducted in East Java, Indonesia. Sugar mill $\mathrm{X}$ and sugar mill $\mathrm{Y}$ are treated as samples and 30 sugarcane farmers were interviews for data acquisition. East Java was chosen as the location of the research because it is the central sugarcane production region of Indonesia (BPS, 2018). Furthermore, sugar mill X, sugar mill Y, and the 30 sugarcane farmers are selected through purposive sampling. These samples represent major conditions in the sugarcane agro-industry of East Java Province. Supply chain's profit and payoff are obtained through field observation and agro-industrial data acquisition then calculated through appropriate methods and tools. Supply chain risk and value added are obtained 
through expert survey and questionnaire, agro-industrial data, and literature review. Finally, the fuzzy Shapley value construction models are developed through literature review and field survey validation.

\subsection{Constructing Supply Chain Profit Calculation}

In general, profit calculation is obtained using Equation 1 and 2. Profit $(\pi)$ is obtained from total revenue $(T R)$ with standard output quantity $(Q)$, price of output $(P)$, total cost $(T C)$, fixed cost $(F C)$, and variable cost $(V C)$.

$\pi=T R-T C$

$\pi=(Q \times P)-(F C+V C)$

Calculating profit for the sugarcane agro-industry supply chain has a unique behavior since there are partnership among supply chain stakeholders. It is commonly found at the farmer and mill level, stakeholders commonly form partnership to increase profit and maintain business stability (Cahyani et al., 2017). On the contrary, farmers, sugar mills, and distributors may perform their business separately without any partnership based on their willingness and decision. Furthermore, profit for stakeholder $i$ without any coalition is represented by $\pi^{\prime}{ }_{i}$, whereas profit for stakeholder $i$ and coalition $j$ is represented by $\pi^{\prime \prime}{ }_{i j}$.

Suppose that farmer, sugar mill, and distributor are represented by A, B, and C, respectively. Therefore, profits of farmers, sugar mills, and distributors without any coalition $\left(\pi^{\prime}{ }_{i}\right)$ are computed using Equations 3,4 , and 5, respectively. $\pi_{A}^{\prime}=\left(Q_{A} \times P_{\text {basic }} \times S C_{A}\right)-\left(F C+V C+\left(\operatorname{Trans} C_{A} \times\right.\right.$ $\left.\left.Q_{A}\right)\right)$

$\pi_{B}^{\prime}=\left(Q_{B} \times P_{b i d}\right)-T C_{B}$

$\pi_{C}^{\prime}=T R_{C}-\left(\left(Q_{B} \times P_{b i d}\right)+\left(P C \times Q_{B}\right)+\right.$

$\left(\right.$ Trans $\left.\left.C_{C} \times Q_{B}\right)\right)$

Farmers' profit without any partnership is calculated with total revenue (TR) and total cost (TC). Farmers' TR with coalition $\pi_{A}$ is obtained from their total sugarcane production $\left(Q_{A}\right)$, basic sugarcane price as regulated by the government $\left(P_{\text {basic }}\right)$, and average sugarcane content $S C_{A}$. TC of sugarcane farmers comprises fixed and variable costs. Fixed costs include land rent, fertilizer, irrigation, and planting and maintenance costs. The variable cost is the sugarcane transportation cost $\left(\operatorname{Trans} C_{A}\right)$ to mills for all sugarcane produced by farmers $\left(Q_{A}\right) . Q_{B}$ stands for total sugarcane produced by sugar mill $B ; P_{\text {bid }}$ is sugar bidding price through market system process; and $P C$ represents distributors' repackaging cost of sugar. Sugar distributors also have to pay transportation cost $\left(\operatorname{Trans}_{C}\right)$ for sugarcane transported from the sugar mill to their warehouse.

Profit calculation in coalition and partnership $\left(\pi^{\prime \prime}{ }_{i j}\right)$ of farmers (A) and sugar mills (B) is defined by Equation 6. A sugar bidding price $\left(P_{\text {bid }}\right)$ for sugarcane, which is highest than sugar basic price $\left(P_{\text {bid }}>P_{\text {basic }}\right)$, is applied. Due to any coalition between farmers and sugar mills, sugarcane content $\left(S C_{A+B}\right)$ is shared between them. For the TC due to any coalitions, subsidy cost will be granted to the farmers by the sugar mills to increase their production $\left(Q_{A+B}\right)$. TC of any partnership between farmers and sugar mills involve fixed cost, variable cost, and transportation cost for both stakeholders, which are represented by $F C_{A+B}, V C_{A+B}$ and $\operatorname{Trans} C_{A+B}$, respectively. Therefore, having a partnership is more profitable than without any coalitions. Equation 6 below also gives information about farmers and sugar mill coalitions' profit.

$\pi_{A B}^{\prime \prime}=\left(Q_{A+B} \times P_{b i d} \times S C_{A+B}\right)-\left(\left(F C_{A+B}+V C_{A+B}\right)+\right.$

$\left.\left(\operatorname{Trans} C_{A+B} \times Q_{A+B}\right)\right)$

A coalition between sugar mill (B) and distributor (C) is detailed in Equation 7. In this coalition profit computation, revenue is obtained through sugar quantity produced through sugar mill and distributor coalition $\left(S Q_{B+C}\right)$, and the price is set to the agreed price $\left(P_{B C}\right)$. TC comprises fixed cost $\left(F C_{B+C}\right)$ and variable cost $\left(V C_{B+C}\right)$ incurred by these stakeholders during coalition.

$\pi_{B C}=\left(S Q_{B+C} \times P_{B C}\right)-\left(F C_{B+C}+V C_{B+C}\right)$

Profit for grand coalition $(N)$ among farmers $(A)$, mills $(B)$, and distributor $(C)$ is computed using Equation 8 . Coalition between farmers $(A)$ and distributors $(C)$ is not calculated because it is restricted and impossible to exist in sugarcane supply chain.

$\pi_{N}=\pi_{A}+\pi_{B}+\pi_{C}$

\subsection{The Shapley Value}

The Shapley value allocates profits among cooperative game players based on their contribution. Suppose $N$ as nonempty and finite set of players who consider coordination in coalitions, $v$ as payoff function of the game, and cooperative games with TUG is represented by $(N, v)$. We denote $R$ as real number, $K$ as a subset of $N(K \subseteq N)$, which refers to a coalition in the game, then $v(K) \in R$ represents the payoff earned by the coalition. In addition, $v(K)\{i\}$ stands as a coalition's payoff without player $i$ or $i$ stands as a dummy player on coalition $K$. Therefore, the Shapley value for player $i$ in the game coalition $\left(\varphi_{i}(v)\right)$ is defined in Equation 9.

$\left.\varphi_{i}(v)=\sum_{K \subseteq N} \frac{(n-|k|) !(|k|-1) !}{n !}[v(k)-v(k) \backslash i)\right], i \in N$

Where $|k|$ is the number of players in coalition $K$ and $n$ is the number of players in the grand coalition $N$. The Shapley value $\varphi_{i}(v)$ is defined as average marginal contribution $v(k)-v(k) \backslash i$ for player $i$ in all possible combinations of coalition $\left(\frac{(n-|k|) !(|k|-1) !}{n !}\right)$. Following certain rules of the Shapley value, if $\emptyset$ stands for an empty coalition, then payoff is $v(\varnothing)=0$. The distribution of coalitions' payoff for all game players is denoted as a real number $x$ $\left(x=\left(x_{i}\right)_{i \in I} \in R\right)$, also called as imputation. Therefore, players will join coalition $K$ if imputation $x$ meets that the distributed payoff of the coalition is better than the payoff without any coalition (Equation 10) and all distributed payoff is the same as all profit gained by coalition (Equation $11)$.

$x_{i} \geq v(\{i\}), \forall i \in N$

$\sum_{i \in I} x_{i}=v(I)$

Furthermore, Shapley also proposed axioms to meet $\varphi_{i}(v)$ as the Shapley value (Shapley, 1953). The Shapley value ensures all profits gained by the coalition should be distributed to all stakeholders. This concept is referred to as the Pareto axioms as defined below (Thun, 2008).

1. Efficiency ensures that all profits of the game will be distributed and accessible to all players in a coalition as expressed in Equations 12 and 13.

$\sum_{i \in N} \varphi_{i}(v)=v(N)$
$\sum_{i \in N} \varphi_{i}(v)=0$, if $i$ as dummy player

2. Symmetry shows that if players $i$ and $j$ join a coalition and have the same contribution to the alliance, then 
they have an equal profit contribution as shown in Equation 14.

$\varphi_{i}(N, v)=\varphi_{j}(N, v)$
3. Additivity stands that the sum of transferrable unit of two games $v_{1}$ and $v_{2}$ in coalition $K$ is the value of the game's achievement as shown in Equation 15. $\varphi_{i}\left(v_{1}+v_{2}\right)=\varphi_{i}\left(v_{1}\right)+\varphi_{i}\left(v_{2}\right), i \in N$

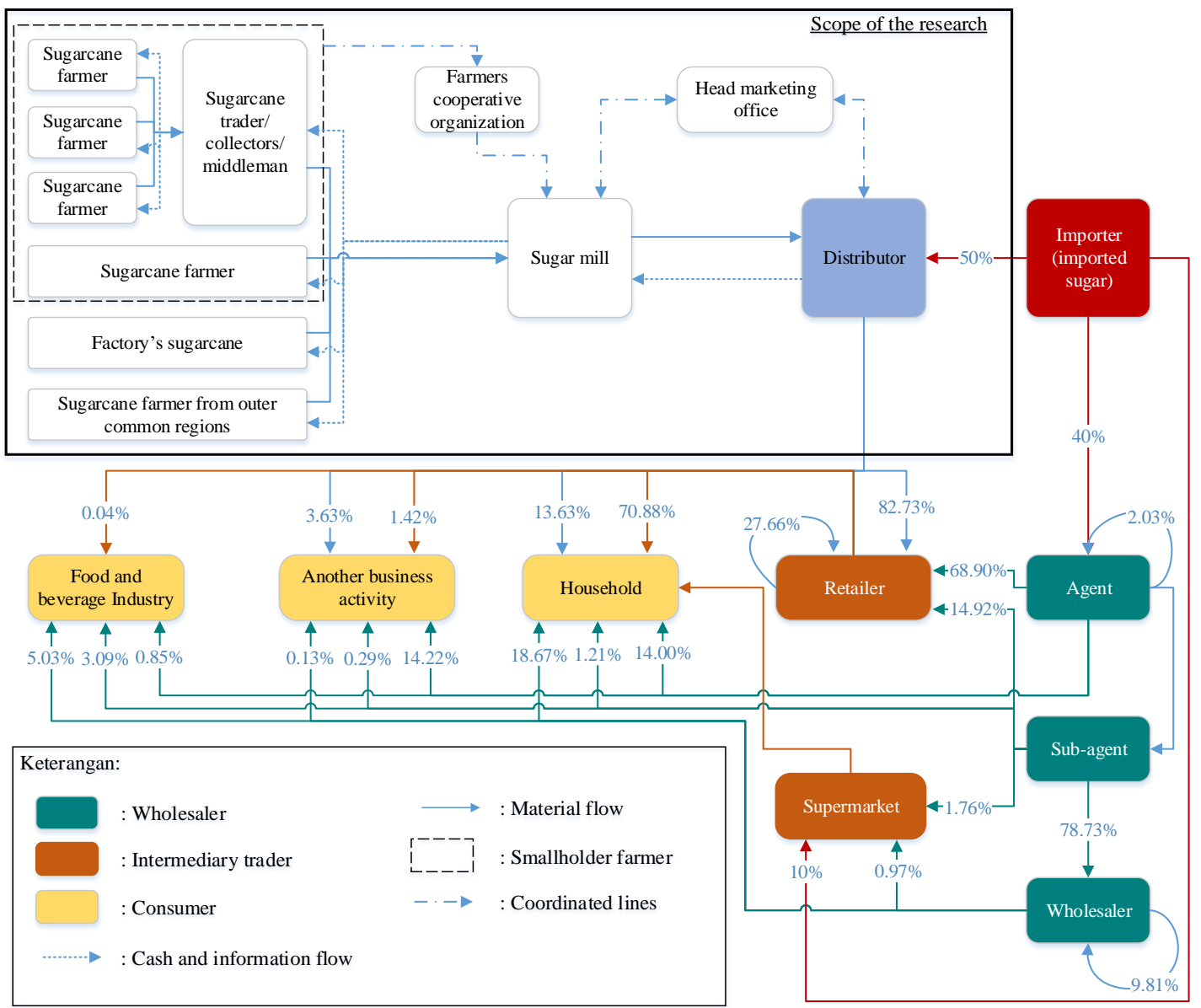

Source: Field observation and (BPS, 2016)

Figure 2 Sugarcane agro-industrial supply chain configuration

The Shapley value also stands for the assumption that players will gain more payoff in a coalition than doing it alone. The maximum profit of the games is achieved when all players cooperate and makes a coalition (Wu, 2010). This assumption is also called as super-additivity, that is, the payoff of coalition $K$ and $S$ must be better than the resulting payoff when they do not cooperate. This assumption is expressed in Equation 16.

$v(i \cup j) \geq i(v)+j(v), i \cap j=\emptyset ; i, j \in N$

\subsection{Supply Chain Risk and Value Added Calculation}

As an important factor and conflict objective in supply chain, risk and value added should be considered to allocate profit among stakeholders fairly. In this research, supply chain risk based on expert assessment is calculated. Many factors in the supply chain are ambiguous, imprecise, only known by experts (Nishizaki and Sakawa, 2000; Gao et al., 2017). Thus, risk should be computed on each supply chain stakeholder by expert assessment using fuzzy set theory. Risk on supply chain stakeholder is calculated following fuzzy-based house of risk framework. Risk on stakeholder $A$ in supply chain is calculated using aggregate risk potential (ARP) as shown in Equations 17 and 18.

$$
\begin{aligned}
& \widetilde{A R P_{J}}=\widetilde{O_{J}} \sum_{i} \widetilde{S_{l}} \widetilde{R_{l j}} \\
& \widetilde{A R P_{A}}=\sum_{j=1}^{J} \widetilde{A R P_{J}}
\end{aligned}
$$

Suppose $\widetilde{O_{J}}$ as the level of occurrence of risk agent $j, \widetilde{S_{l}}$ as the level of severity of risk event $i$, and $\widetilde{R_{\imath \jmath}}$ as the level of correlation of risk agent $i$ and risk event $j$. The level of occurrence, severity, and correlation are modeled in triangular fuzzy number (TFN). Therefore, the arithmetic process of finding $\widehat{A R P}_{A}$ value is solved using fuzzy operations as defined by Marimin et al. (1998).

Supply chain value added for sugarcane agro-industry is calculated using the model reported by Hayami et al. (1987) and Hidayat et al. (2012). Each supply chain value added of stakeholders is calculated from their contribution that adds value to supply chain main materials. Value added is related to stakeholders' revenue after adding value to the materials for production in stakeholders' final phase. Therefore, to generalize this value, value-added as value-added ratio is represented as shown in Equation 19.

$$
\text { value }- \text { added ratio }(\%)=\frac{\text { value added }}{\text { product value }}
$$




\section{RESULT AND DISCUSSION 4.1. Sugarcane Supply Chain Configuration and Its Profit}

Identifying supply chain configuration is the first and ultimate stage in solving supply chain problems (Muchfirodin et al., 2015). As aforementioned, sugarcane agro-industrial supply chain was identified as a case study on this research. In general, business process in sugarcane agroindustry supply chain is supported by primary and secondary stakeholders. Primary stakeholders ensure material, information, and cash flow among all stakeholders for the maximization of their profit. They involve farmers, sugar mills, and distributors. Secondary stakeholders assist primary stakeholders in completing their activities in supply chain alliance through cooperation and coordination.

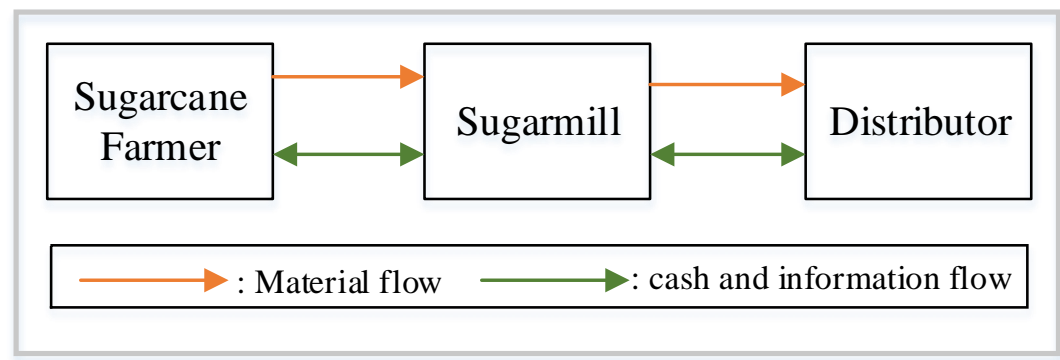

Figure 3 Sugarcane supply chain stakeholders considered in the model

Secondary stakeholders in sugarcane agro-industry supply chain include farmers' cooperative organization, research institutions, regional government, and head marketing office. The supply chain configuration of East Java Province is described in this study based on the real condition of its sugarcane supply chain. The sugarcane supply chain configuration and sugar presentation flow among stakeholders in East Java Province is shown in Figure 2.

This research focuses on the scope of primary supply chain stakeholders that involve farmers, sugar mills, and distributors. The primary supply chain stakeholders are related due to fair profit sharing among stakeholders, which is done by many business activities to produce sugarcane and sugar. Figure 2 shows the primary stakeholders in the sugarcane supply chain considered in this research. A group of smallholders comprised of sugarcane farmers is simplified to define well the problem of profit allocation and distribution. Furthermore, the primary stakeholders are involved in the profit allocation model in the following discussions.

As can be seen in Figure 3, supply chain alliance develops coalitions, namely, farmer-sugar mill, sugar milldistributor, and grand coalitions for all supply chain stakeholders. Due to this coalition, fair profit allocation should be completed. Unequal profit allocation among sugarcane supply chain stakeholders is the key factor and main problem of supply chain performance since its low situation. The first stage in profit allocation in the coalition is computing and determining stakeholders' profit in the current situation.

Based our model on Equations 1-8, profits for each stakeholder and coalition are calculated. The possible profit calculation on sugarcane agro-industrial supply chain is $\pi_{A}^{\prime}, \pi_{B}^{\prime}, \pi_{C}^{\prime}, \pi^{\prime \prime}{ }_{A B}, \pi^{\prime \prime}{ }_{B C}, \pi^{\prime \prime}{ }_{N}$. Because our method in this research using the Shapley value does not conflict in interest, profit $(\pi)$ as the payoff $(v)$ on supply chain is renamed. Therefore, profit for farmers, sugar mills, distributor, farmer-mill coalition, mill-distributor coalition, and grand coalitions are represented by $v(A), v(B), v(C), V(A, B), V(B, C)$, and $v(N)$, respectively. Finally, the result of profit calculation in the sugarcane agro- industrial supply chain is shown in Table $\mathbf{1}$. The basic calculation on this profit is based on 1 ha sugarcane field. Based on this result, farmer $V(A)$, sugar mill $V(B)$, and distributor $V(B)$ profit are represented as the current situation of the sugarcane agro-industrial supply chain.

Table 1 Sugarcane agro-industrial supply chain profits

\begin{tabular}{lll}
\hline \multicolumn{1}{c}{ Coalitions } & \multicolumn{1}{c}{ Symbol } & Profit (IDR) \\
\hline Farmer & $V(A)$ & 3985645.00 \\
Sugar mill & $V(B)$ & 2581000.00 \\
Distributor & $V(C)$ & 9710766.00 \\
Coalition between farmer & $V(A, B)$ & 5016795.00 \\
$\begin{array}{l}\text { and sugar mill } \\
\text { Coalition between sugar } \\
\text { mill and distributor }\end{array}$ & $V(B, C)$ & 10669854.00 \\
Grand coalition & $V(N)$ & 18868942.00 \\
\hline
\end{tabular}

\subsection{Sugarcane Supply Chain Profit Allocation}

The classical Shapley value is proposed to fairly allocate profit among all supply chain stakeholders. Equation 9 shows the distribution of profits among all stakeholders based on their marginal contribution to the supply chain alliance. Profit allocation for farmers is shown in Table 2. Applying the Shapley value algorithm shows that sugarcane farmers should gain $\varphi_{A}(v)$ IDR 4467543.50 . As shown in Figure 2, a coalition does not exist between farmer and distributor $v(A, C)$, similar to the profit allocation scheme. Using the same formula and algorithm, we also found that sugar mill allocation $\varphi_{B}(v)$ is IDR 7481687.00 and distributor allocation is IDR 9202446.67.

Table 2 Profit allocation for sugarcane farmer (IDR)

\begin{tabular}{lccc}
\hline \multicolumn{1}{c}{ Coalition } & A & A, B & A, B, C \\
\hline$v(K)$ & 3985645.00 & 5016795.00 & 18868942.00 \\
$v(K \backslash A)$ & 0 & 2581000.00 & 10669854.00 \\
$v(K)-v(K \backslash$ & & & \\
$A)$ & 3985645.00 & 2435795.00 & 8199088.00 \\
$|k|$ & 1 & 2 & 3 \\
\hline
\end{tabular}


Table 2 Profit allocation for sugarcane farmer (IDR) (cont')

\begin{tabular}{lccc}
\hline \multicolumn{1}{c}{ Coalition } & A & A, B & A, B, C \\
\hline$n+(|k|-1) !(n-|k|) !$ & 3 & 3 & 3 \\
$n !$ & 0.33 & 0.17 & 0.33 \\
$\frac{(|k|-1) !(n-|k|) !}{n !} \times$ & & & \\
{$[v(K)-v(K \backslash$} & 1328548.33 & 405965.83 & 2733029.33 \\
$A)]$ & & & \\
\hline Farmers' & & & 4467543.50 \\
allocated profit & & & \\
$\varphi_{A}(v)$ & & & \\
\hline
\end{tabular}

The Shapley value has set up profit allocation solutions for supply chain alliance in sugarcane agroindustry based on stakeholders' marginal contributions. This result is better than the current situation found in the real case. Figure 3 shows a comparison between the profit allocation in the real world and based on the Shapley value. Profit allocation model using the Shapley value is more realistic than current situations. This algorithm gives a realization that sugarcane supply chain profit allocation is not balanced and fair. Therefore, profit should be allocated profit fairly among stakeholders.

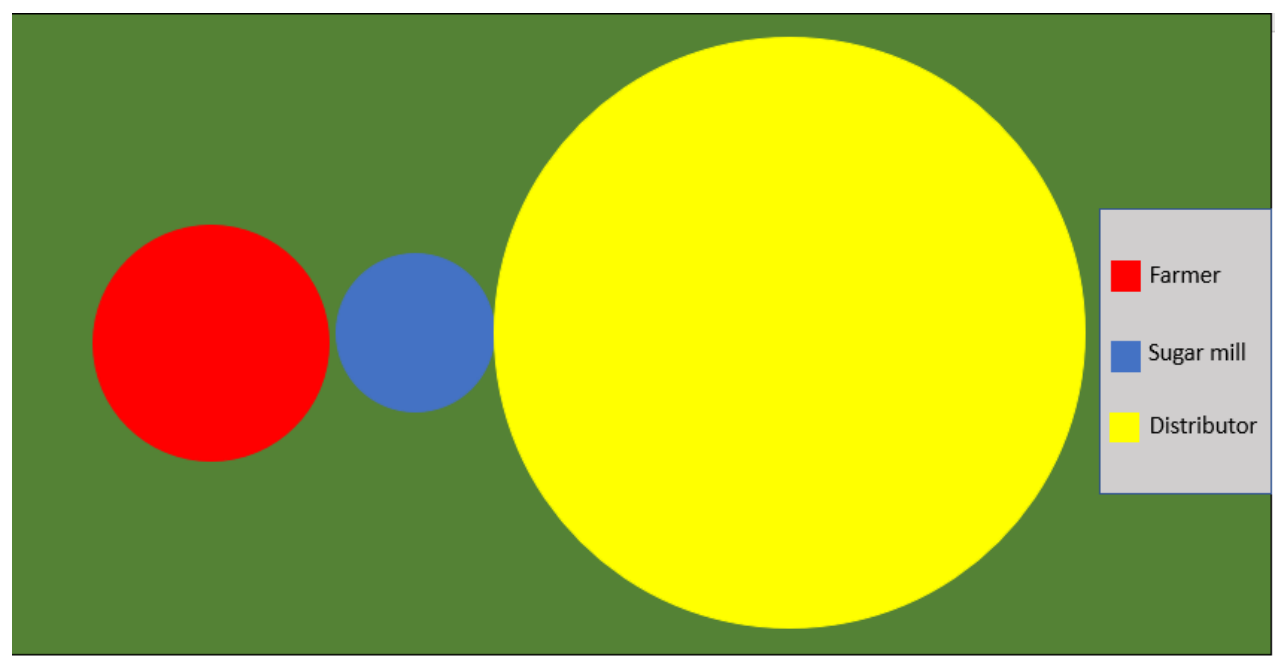

(a)

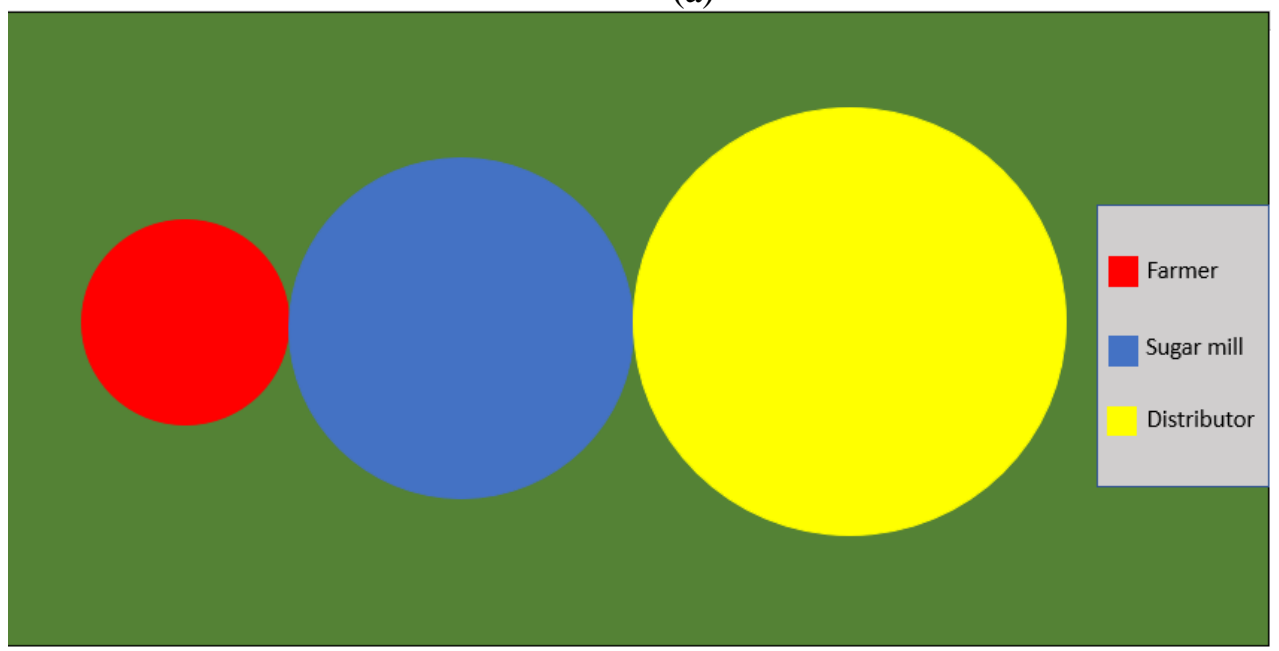

(b)

Figure 4 Sugarcane agro-industrial supply chain profit allocations based on (a) current situation and (b) the Shapley value result

The above profit allocation model and result entails few important notes. Table 2 shows that the sum of the probability that stakeholders join coalitions is less than 1 $\left(\sum \frac{(|k|-1) !(n-|k|) !}{n !}<1\right)$, which does not meet the Shapley axioms. This supply chain is not in complete coalitions scheme due to the absence of coalition between farmers and distributors $(v(A, C)=\emptyset)$, referred to as restricted coalitions (Myerson, 1977; Thun, 2008). Table 1 shows that in the real-world case, stakeholders are not aware of their appropriate payoff. Determining stakeholders' payoff in a crisp number is unacceptable, unreal, and thus not applicable in the real world (Nishizaki and Sakawa, 2001b; Borkotokey,
2008). As a result, we consider fuzzy set theory to accommodate uncertain payoff and profit and incomplete information for solving profit allocations (Gao et al., 2011; $\mathrm{Xu}$ et al., 2014).

\subsection{Fuzzy Cooperative Games for Fair Profit Allocation}

As defined by Shapley (1953), $\varphi_{i}(v)$ is referred to as the Shapley value if and only if it fulfills the axioms. Table 1 shows that it did not fulfill super-additivity assumptions as expressed at Equation 16. To maintain this assumption for solving uncertain payoff allocation problems, it should be extended to fuzzy variable (Mares, 2001). Additionally, 
decision making in agro-industrial supply chain is dominated by uncertain and vague variables that do not provide sufficient information to players in the determination of their profit if they join a coalition. This situation should be addressed due to the increasing appropriate solutions based on real conditions (Kumari et al., 2014).

Solving profit allocation problems in sugarcane agroindustrial supply chains through cooperative games deals with uncertain payoffs and incomplete information. Thus, the Shapley value $(N, v)$ has to be extended to fuzzy Shapley value $(N, \tilde{v})$ (Mares, 2001; Abed-Elmdoust and Kerachian, 2012). Involving fuzzy parameters for solving mathematical problems and group decision making is more realistic than the classical version. Fuzzy set theory also offers an appropriate definition for a real situation that has incomplete information to find appropriate solutions (Nishizaki and Sakawa, 2000; Gao et al., 2011; Huang et al., 2018).

In the classical Shapley value expressed in Equation 9, payoff $v$ stands for a crisp real number $(R)$. The payoff on the fuzzy Shapley value is expressed as fuzzy number or interval number to fulfill the Shapley assumptions on superadditivity. Here the concept of the fuzzy Shapley value for agro-industrial supply chain is introduced. Suppose that $(N, \tilde{v})$ as the extension of the Shapley value $(N, v)$ in a cooperative game with $N\{1,2, \ldots, \mathrm{n}\}$ players and uncertain payoff $(\tilde{v}) . \tilde{v}(K)$ as an extension of $v(K)$, and define over the set of all fuzzy numbers $(\mathfrak{R})$ and $\tilde{v}(\varnothing)=0$. In this case, Triangular Fuzzy Number (TFN) was applied to re-define stakeholders' payoff ( $\tilde{v})$ and accommodate the uncertainty in the real-world situation. TFN represented the uncertainty in stakeholder payoff gained by joining a supply chain coalition and met the efficiency axioms of the Shapley value (Chen et al., 2007; Abed-Elmdoust and Kerachian, 2012).

In general theory of fuzzy sets, fuzzy number has a membership function or confidence level that was proposed by Zadeh (1965). As payoff is expressed in TFN, $\tilde{v}(K)$ is transformed into interval value $\left[\tilde{v}_{\alpha}^{L}(K), \tilde{v}_{\alpha}^{R}(K)\right]$ with $\alpha$ denoted as a membership function of payoff fuzzy numbers $\mu_{\tilde{v}(K)}(v)$. Then, $\tilde{v}_{\alpha}^{L}(K)$ and $\tilde{v}_{\alpha}^{R}(K)$ stands for minimal and maximal payoff value of coalition $K$, respectively. TFN is transformed because expressing the payoff function in interval value is more realistic (Nishizaki and Sakawa, 2001; Wang et al., 2014). Therefore, for any TFN $I\left(I_{1}, I_{2}, I_{3}\right)$ where $I_{1}<I_{2}<I_{3}$ and $\alpha$ as confidence level of membership function, Marimin et al. (1998) define the transformation process of fuzzy number into interval value as expressed in Equation 20.

$I_{\alpha}=\left[\left(I_{2}-I_{1}\right) \alpha+I_{1},-\left(I_{3}-I_{2}\right) \alpha+I_{3}\right]=\left[I_{a}^{L}, I_{a}^{R}\right]$

Furthermore, as fuzzy number is transformed into an interval value, the arithmetic operation below is used. Let $I, J$, and $x$ as real number $(\mathrm{R})$ with $I=\left[I^{L}, I^{R}\right]$ and $J=$ $\left[J^{L}, J^{R}\right]$ and $m(I)$ as a mid-point of interval number $I$, which is defined as $m(I)=\left(\frac{I^{L}+I^{R}}{2}\right)$. The operations of interval values refers to Ganesan (2005), Jain (2010), and Fei et al. (2018) as stated below:

(1) $I=L$; if and only if $I^{L}=J^{L}$ and $I^{R}=J^{R}$

(2) $I+J=\left[I^{L}, I^{R}\right]+\left[J^{L}, J^{R}\right]=[(m(I)+m(J))-$

$k,(m(I)+m(J))+k]$

With $k=\frac{\left(J^{R}+I^{R}\right)-\left(J^{L}+I^{L}\right)}{2}$
(3) $I-J=\left[I^{L}, I^{R}\right]-\left[J^{L}, J^{R}\right]=[(m(I)-m(J))-$

$k,(m(I)-m(J))+k]$,

with $k=\frac{\left(J^{R}+I^{R}\right)-\left(J^{L}+I^{L}\right)}{2}$

(4) $I \times J=\left[I^{L}, I^{R}\right] \times\left[J^{L}, J^{R}\right]=[(m(I) m(J))-$ $k,(m(I) m(J))+k]$,

With $\quad k=\min ((m(I) m(J))-\alpha, \beta-$

$(m(I) m(J))) ; \alpha=\min \left(I^{L} J^{L}, I^{L} J^{R}, I^{R} J^{L}, I^{R} J^{R}\right) ;$

$\beta=\max \left(I^{L} J^{L}, I^{L} J^{R}, I^{R} J^{L}, I^{R} J^{R}\right)$.

(5) $x I=x \times\left[I^{L}, I^{R}\right]=\left[x I^{L}, x I^{R}\right], x$ as real number

(6) For interval value normalization, suppose $\sum x_{i}$ as total interval value to be normalized. Therefore, normalization of interval $\left[I^{L}, I^{R}\right]=\frac{I}{\sum x_{i}}=\frac{\left[I^{L}, I^{R}\right]}{\left[\sum x_{i}{ }^{L}, \sum x_{i}{ }^{R}\right]}=$ $\left[\frac{I^{L}}{\sum x_{i}{ }^{L}+\sum x_{i}^{R}}, \frac{I^{R}}{\sum x_{i}^{L}+\sum x_{i}^{R}}\right]$

A fuzzy cooperative game $(N, \tilde{v})$ is called superadditive if any $\alpha[0,1]$ and any two coalitions $S, T \in I, S \cap$ $T=\emptyset$ meet the following:

$\tilde{v}_{\alpha}^{L}(S \cup T) \geq \tilde{v}_{\alpha}^{L}(S)+\tilde{v}_{\alpha}^{L}(T)$

$\tilde{v}_{\alpha}^{R}(S \cup T) \geq \widetilde{v}_{\alpha}^{R}(S)+\widetilde{v}_{\alpha}^{R}(T)$

Evidently, stakeholders would achieve more profit when joining a coalition (Nishizaki and Sakawa, 2000; Chen et al., 2007), which also means that stakeholders are willing to cooperate with each other.

The fuzzy Shapley value is defined with optimistic value $\alpha$ as the membership function of TFN. Using this value, fuzzy payoff is transformed into TFN which will have $\left[\tilde{v}_{\alpha}^{L}(K), \tilde{v}_{\alpha}^{R}(K)\right]$. To define fuzzy Shapley value, it has to meet Shapley axioms as states and proofs below.

1. Efficiency, that all fuzzy profits or Shapley value of the game $\left(\varphi_{i}(\tilde{v})\right)$ will be distributed and accessible for all players in coalition and dummy player will not get any as there is no contribution to the coalition, as expressed below.

$\sum_{i \in N}$ $\varphi_{i}^{\alpha}(\tilde{v})$

$=\tilde{v}(N) ; \alpha$ as optimistic value of membership function $\sum_{i \in N} \varphi_{i}^{\alpha}(\tilde{v})=0$, if $i$ as dummy player

2. Symmetry, that if player $i$ and player $j$ join in a coalition and have same contribution to the coalition, then they have equal profit allocation, as detailed below.

$$
\widetilde{\varphi}_{l}(N, \tilde{v})=\widetilde{\varphi_{J}}(N, \tilde{v})
$$

Proof. From Equation 13 (Shapley's symmetry axiom), we known that:

$$
\varphi_{i}(N, v)=\varphi_{j}(N, v)
$$

Therefore, $\tilde{v}_{\alpha}^{i}(k)=\tilde{v}_{\alpha}^{j}(k)$ if and only if $i, j \in N$ which have identical contribution to coalition $k$. Then, based on Equation 9, we can formulate that:

$$
\begin{aligned}
& \left.\tilde{\varphi}_{i}^{\alpha L}(\tilde{v})=\sum_{K \subseteq N} \frac{(n-|k|) !(|k|-1) !}{n !}\left[\tilde{v}_{\alpha}^{i L}(k)-\tilde{v}_{\alpha}^{i L}(k) \backslash i\right)\right]= \\
& \left.\sum_{K \subseteq N} \frac{(n-|k|) !(|k|-1) !}{n !}\left[\tilde{v}_{\alpha}^{j L}(k)-\tilde{v}_{\alpha}^{j L}(k) \backslash j\right)\right]=\tilde{\varphi}_{j}^{\alpha L}(\tilde{v}) \\
& \left.\tilde{\varphi}_{i}^{\alpha R}(\tilde{v})=\sum_{K \subseteq N} \frac{(n-|k|) !(|k|-1) !}{n !}\left[\tilde{v}_{\alpha}^{i R}(k)-\tilde{v}_{\alpha}^{i R}(k) \backslash i\right)\right]= \\
& \left.\sum_{K \subseteq N} \frac{(n-|k|) !(|k|-1) !}{n !}\left[\tilde{v}_{\alpha}^{j R}(k)-\tilde{v}_{\alpha}^{j R}(k) \backslash j\right)\right]=\tilde{\varphi}_{j}^{\alpha R}(\tilde{v})
\end{aligned}
$$


Therefore, this process informed us that $\widetilde{\varphi}_{l}(N, \tilde{v})=\widetilde{\varphi_{J}}(N, \tilde{v})$

3. Additivity, that the sum of transferable unit of 2 game $\tilde{v}_{1}$ and $\tilde{v}_{2}$ in coalition $K$ is the value of what the game achieved as detailed below.

$$
\widetilde{\varphi}_{l}\left(\tilde{v}_{1}+\tilde{v}_{2}\right)=\widetilde{\varphi}_{l}\left(\tilde{v}_{1}\right)+\widetilde{\varphi}_{l}\left(\tilde{v}_{2}\right), i \in N
$$

Proof. Fuzzy Interval Shapley value, informed us that:

$$
\begin{aligned}
& \tilde{\varphi}_{i}^{\alpha L}(\tilde{v})=\sum_{K \subseteq N} \frac{(n-|k|) !(|k|-1) !}{n !}\left[\tilde{v}_{\alpha}^{L}(k)-\tilde{v}_{\alpha}^{L}(k) \backslash i\right], \\
& \tilde{\varphi}_{i}^{\alpha R}(\tilde{v})=\sum_{K \subseteq N} \frac{(n-|k|) !(|k|-1) !}{n !}\left[\tilde{v}_{\alpha}^{R}(k)-\tilde{v}_{\alpha}^{R}(k) \backslash i\right]
\end{aligned}
$$

Therefore, from Equation 9, Equation 15 (additivity axiom), interval arithmetic operations, we know that:

$$
\begin{aligned}
& \tilde{\varphi}_{i}^{L}\left(\tilde{v}_{1}+\tilde{v}_{2}\right)=\sum_{K \subseteq N} \frac{(n-|k|) !(|k|-1) !}{n !}\left[\left(\left(\tilde{v}_{1}^{L}+\tilde{v}_{2}^{L}\right)(k)\right)-\right. \\
& \left.\left.\left(\left(\tilde{v}_{1}^{L}+\tilde{v}_{2}^{L}\right)(k) \backslash i\right)\right)\right] \\
& =\sum_{K \subseteq N} \frac{(n-|k|) !(|k|-1) !}{n !}\left[\left(\tilde{v}_{1}^{L}(k)+\tilde{v}_{2}^{L}(k)\right)-\left(\tilde{v}_{1}^{L}(k) \backslash i+\right.\right. \\
& \left.\left.\tilde{v}_{2}^{L}(k) \backslash i\right)\right] \\
& =\sum_{K \subseteq N} \frac{(n-|k|) !(|k|-1) !}{n !}\left[\left(\tilde{v}_{1}^{L}(k)-\tilde{v}_{1}^{L}(k) \backslash i\right)+\left(\tilde{v}_{2}^{L}(k)-\right.\right. \\
& \left.\left.\tilde{v}_{2}^{L}(k) \backslash i\right)\right] \\
& =\sum_{K \subseteq N} \frac{(n-|k|) !(|k|-1) !}{n !}\left[\left(\tilde{v}_{1}^{L}(k)-\tilde{v}_{1}^{L}(k) \backslash i\right)\right]+ \\
& \sum_{K} \subseteq N \frac{(n-|k|) !(|k|-1) !}{n !}\left(\tilde{v}_{2}^{L}(k)-\tilde{v}_{2}^{L}(k) \backslash i\right) \\
& =\tilde{\varphi}_{i}^{L}\left(\tilde{v}_{1}\right)+\tilde{\varphi}_{i}^{L}\left(\tilde{v}_{2}\right) \\
& \quad \text { We can also proof that } \tilde{\varphi}_{i}^{R}\left(\tilde{v}_{1}+\tilde{v}_{2}\right)=\tilde{\varphi}_{i}^{R}\left(\tilde{v}_{1}\right)+ \\
& \tilde{\varphi}_{i}^{R}\left(\tilde{v}_{2}\right) . \text { Therefore, it concludes that } \widetilde{\varphi}_{l}\left(\tilde{v}_{1}+\tilde{v}_{2}\right)= \\
& \widetilde{\varphi}_{l}\left(\tilde{v}_{1}\right)+\varphi_{i}\left(\tilde{v}_{2}\right) .
\end{aligned}
$$

Therefore, Shapley value for fuzzy payoff cooperative games to applied in supply chain coalitions is defined as Equation 21.

$$
\left.\tilde{\varphi}_{i}^{\alpha}(\tilde{v})=\sum_{K \subseteq N} \frac{(n-|k|) !(|k|-1) !}{n !}\left[\tilde{v}_{\alpha}(k)-\tilde{v}_{\alpha}(k) \backslash i\right)\right], i \in N
$$

Rather than TFN transformation to the interval value, the above equation is rewritten as Equation 22, where $\tilde{v}(\varnothing)=[0,0]$.

$$
\begin{gathered}
\tilde{\varphi}_{i}^{\alpha L}(\tilde{v})=\sum_{K \subseteq N} \frac{(n-|k|) !(|k|-1) !}{n !}\left[\tilde{v}_{\alpha}^{L}(k)\right. \\
\left.\tilde{\varphi}_{i}^{\alpha R}(\tilde{v})=\sum_{K \subseteq N} \frac{(n-|k|) !(|k|-1) !}{n !}\left[\tilde{v}_{\alpha}^{R}(k) \backslash i\right)\right], \\
\left.\left.-\tilde{v}_{\alpha}^{R}(k) \backslash i\right)\right], i \in N
\end{gathered}
$$

Note that:

$\sum_{K \subseteq N} \frac{(n-|k|) !(|k|-1) !}{n !}=1$

The Shapley's profit allocation depends on marginal contribution to the grand coalition, which means that we have to notice the supply chain cooperation structure. In the real supply chain, not all coalitions are possible due to restricted cooperation, lack of communication, or institutional constraints as investigated by Myerson (1977) and Jian-gang and Guang-dong (2009). Our supply chain structure shows that any coalition exists between sugarcane farmers and distributors. We also found that the probability of sugarcane farmers and distributors in joining coalitions did not fulfill the axioms $\left(\sum \frac{(|k|-1) !(n-|k|) !}{n !}<1\right)$; reasonably, it should be equal to 1 .
Thun (2008) has proven this problem using Equation 23. Profit allocations for stakeholders will be higher in a complete coalition than in a restricted coalition. means that there is a possible an unconnected coalition link in the supply chain alliance among stakeholders $(\backslash i: j)$ May exist in a restricted coalition. Using the classical equation defined by Shapley will result in unstable profit allocation where profit goes to a focal player. Therefore, for restricted coalitions, such supply chain alliance may be assumed as a graph (Myerson, 1977; Aumann and Myerson, 1988). The Shapley value for stakeholders $i$ without any path to stakeholders $j$ in coalition $\mathrm{S}$ is $i$ 's payoff as stated in Equation 24 .

$\tilde{\varphi}_{i}^{\alpha}(\tilde{v}) \geq \tilde{\varphi}_{i}^{\alpha}(\tilde{v} \backslash i: j)$ and $\tilde{\varphi}_{j}^{\alpha}(\tilde{v}) \geq \tilde{\varphi}_{j}^{\alpha}(\tilde{v} \backslash i: j)$

$\tilde{\varphi}_{i}^{\alpha}(\tilde{v})=\sum_{K \subseteq N \backslash i: j} \frac{(n-|k|) !(|k|-1) !}{n !}\left[\tilde{v}_{\alpha}(k)\right]$

Myerson (1977) and Aumann and Myerson (1988) stated that the player who has many connections to another game player will gain better payoff. However, it is not real in the actual case. Our case found that sugar mill (B) is a focal player that has many connections to another player. Using the Shapley value in establishing a profit allocation method for sugar mills is found to be an unreal solution, which gives extremely high payoff compared with another player's contribution. This condition is due to the absence of coalitions between farmers and distributors $(v(A, C))=\emptyset)$. Therefore, sugar mills gain all grand coalition payoff $(v(N))$ as the Shapley value proposed. The grand coalition payoff gained by sugar mills should be revised by reducing farmers and distributors' payoff to make it real, though no coalition exists among them. The revision of the Shapley value for sugar mills has been conducted due to the absence of coalitions between farmers and distributor as show in Equation 25.

$$
\begin{aligned}
& \quad \tilde{\varphi}_{B}^{\alpha}(\tilde{v})=\sum_{K \subseteq N \backslash A: C} \frac{(n-|k|) !(|k|-1) !}{n !}\left[\tilde{v}_{\alpha}(N)-\tilde{v}_{\alpha}(A)-\right. \\
& \left.\tilde{v}_{\alpha}(C)\right]
\end{aligned}
$$

\subsection{Improving Profit Allocation through the Fuzzy Shapley Value Considering Risk and Value Added}

As stated by many scholars, one of the limitations of the Shapley value is that it allocates profit based only to stakeholders' average marginal contribution to coalitions (Gao and Shi, 2010; Xu et al., 2014; Alahmari et al., 2017; $\mathrm{Hu}$ and Feng, 2017; Yang et al., 2017). Considering that stakeholders face difference risks and value-added contributions to the coalition, these factors must be considered in a fair profit allocation. Thus, risk and value added are required in the fuzzy Shapley value as correction factors of profit allocations. This idea is appropriate based on previous research by Gao and Shi (2010) and Suharjito and Marimin (2012), who proposed to distribute high profit for stakeholders who bear with higher risk. Additionally, Hidayat (2012) showed that higher profit share must be given to stakeholders who have high investments. Moreover, no research has been conducted on risk and value added comprehensively as factors for fair profit allocation among supply chain stakeholders.

Risk and value-added are conflicting objectives on supply chain management, where risk entails negative impact and value added becomes a positive advantage. Supply chain risk is defined as the probability of a negative 
occurrence that interrupts supply chain activities. Supply chain risk management is required, which involves identification, assessment, and mitigations to minimize the supply chain risk. In addition, value added is referred to as the increase in raw materials; value given the additional specific input and process through sequencing complex process flow (Yao et al., 2008).

In the classical Shapley value, risk is assumed to be equal for all stakeholders with $\frac{1}{n}$; $(n=$ number of stakeholders in the alliance). Distribution risk among supply chain stakeholders has not been equally appropriate for profit allocation because different stakeholders face different risks. Therefore, our methodology above proposed to calculate risk based on expert assessment and found Aggregate Risk Potential (ARP) for each stakeholder. Normalized ARP for each stakeholder value can be revised to establish a profit allocation scheme. The number of risks on supply chain stakeholder $A$ for revised profit allocation is obtained using Equations 26 and 27.

$\Delta R_{A}=R_{A}-\frac{1}{n}$

$=\left(\frac{A R P_{A}}{\sum A R P}\right)-\frac{1}{n}$

As aforementioned, value added gives positive advantage to the supply chain. Stakeholders who produce highest value added should be rewarded with appropriate profit allocation. Value added as calculated on Equation 17 is also normalized to improve supply chain profit allocation. Value added for stakeholder $A$ is defined using Equation 28. $\Delta V A_{A}=\frac{V A_{A}}{\sum V A}$

As risk and value added have been calculated and normalized, these values have to be included in the profit allocation formula. Our final formula to allocate fair profit allocation with consideration of balanced risk and value added on supply chain alliance is obtained through Equation 29.

$$
\begin{gathered}
\left.\tilde{\varphi}_{A}^{\alpha}(\tilde{v})=\sum_{K \subseteq N} \frac{(n-|k|) !(|k|-1) !}{n !}\left[\tilde{v}_{\alpha}(k)-\tilde{v}_{\alpha}(k) \backslash i\right)\right]+ \\
\left(\left(R_{A}-\frac{1}{n}\right) \times \tilde{v}(N)\right)+\left(V A_{A} \times \tilde{v}(N)\right)(29)
\end{gathered}
$$

Equation 29 needs appropriate definition. Suppose that a coalition $K$ involves stakeholder $A, B$, and $C$. No coalition exist between $\mathrm{A}$ and $\mathrm{B}$ in the coalition $K$ $(K \subseteq N \backslash i: j)$. Therefore, with the absence of coalition with stakeholders $C(K \subseteq N \backslash i: j)$, the Shapley value for stakeholder $A$ is stated using Equation 30. Furthermore, with the absence of coalition between $i$ and $j$ in coalition $K$ $(K \subseteq N \backslash i: j)$, the Shapley value for stakeholder $B$ is shown in Equation 31.

$$
\begin{aligned}
& \tilde{\varphi}_{A}^{\alpha}(\tilde{v})=\sum_{K \subseteq N \backslash A: C} \frac{(n-|k|) !(|k|-1) !}{n !}\left[\tilde{v}_{\alpha}(k)-\tilde{v}_{\alpha}(k) \backslash\right. \\
& A)]+\left(\left(R_{i}-\frac{1}{n}\right) \times \tilde{v}(N)\right)+\left(V A_{i} \times \tilde{v}(N)\right) \\
& \tilde{\varphi}_{B}^{\alpha}(\tilde{v})=\sum_{K \subseteq N \backslash A: C} \frac{(n-|k|) !(|k|-1) !}{n !}\left[\tilde{v}_{\alpha}(N)-\tilde{v}_{\alpha}(A)-\right. \\
& \left.\tilde{v}_{\alpha}(C)\right]+\left(\left(R_{i}-\frac{1}{n}\right) \times \tilde{v}(N)\right)+\left(V B_{i} \times \tilde{v}(N)\right)
\end{aligned}
$$

\subsection{Model Assumptions}

The assumptions used in developing the model include the following:
1. Supply chain stakeholders are willing to form a coalition and coordinate with each other to achieve their goals.

2. All stakeholders should identify their profit/payoff before and after forming a coalition to share supply chain profits.

3. The base computation units should be determined to calculate supply chain profit. In this case, this research denotes 1 ha of sugarcane field as base unit to calculate all supply chain stakeholder profit. All stakeholders' profit is calculated according to the base units. Therefore, the profit share for all stakeholders is determined.

4. Risk and value added are identified on each supply chain stakeholder.

5. The weighted Shapley value for stakeholder $i$ $\left(\frac{(n-|k|) !(|k|-1) !}{n !}\right)$ should be equal to 1 , which means that all stakeholders form a coalition. If $\frac{(n-|k|) !(|k|-1) !}{n !}<1$, then it should be normalized.

6. This research has not considered any return on investment (ROI) and return on assets (ROA). Moreover, it focused on the profit share of each stakeholder using specific basic calculations based on 1 ha of sugarcane field.

\subsection{Fair Profit Allocation in Sugarcane Supply Chain Based on Balanced Risk and Value Added}

Uncertain payoff and profit on sugarcane supply chain are accommodated using fuzzy number. As aforementioned, the fuzzy number is transformed to the interval number to

\begin{tabular}{|c|c|}
\hline Coalitions & Symbol Profit (IDR) \\
\hline Farmer & $V(A) \quad[3387798.25, \quad 4224$ 783.70] \\
\hline Sugar mill & [2 $193850.00, \quad 2968$ 150.00] \\
\hline Distributor & [8 254 151.10, 11167 380.90] \\
\hline $\begin{array}{l}\text { Farmer-sugar mill } \\
\text { coalition }\end{array}$ & $V(A, B) \quad[4264$ 275.75, 5769 314.25] \\
\hline $\begin{array}{l}\text { Sugar mill-distributor } \\
\text { coalition }\end{array}$ & $V(B, C) \quad[9069375.90,12270332.10]$ \\
\hline Grand coalition & [16 038 600.70, 21699 283.30] \\
\hline
\end{tabular}
make it realistic. The uncertain profit of sugarcane stakeholders in sugarcane agro-industrial supply chain is shown in Table 3. Data is obtained from sugarcane agroindustry in Indonesia. Therefore, payoffs are in IDR units.

Table 3 Sugarcane agro-industrial supply chain profits

Risk and value added values for sugarcane agroindustrial supply chain are conducted through previous research. ARP is used to obtain risk value on sugarcane supply chain and supply chain value added for farmers, and sugar mill is obtained from Asrol (2018). Moreover, distributors' value added is conducted from BPS (2016). Table 4 shows sugarcane supply chain risk and value added for all stakeholders in the sugarcane agro-industry.

Due to improved supply chain profit allocation through the Shapley value, risk and value added have to be normalized. Table 4 shows that risk and value added in sugarcane agro-industrial supply chain are normalized using 
Equations 26-28. Similar to an interval scale, the operations follow interval arithmetic, and results are shown in Table 5.

Table 4 Uncertain sugarcane supply chains risk and value added

\begin{tabular}{|c|c|c|c|c|}
\hline $\begin{array}{l}\text { Supply } \\
\text { chain } \\
\text { stakeholder }\end{array}$ & Aggregate & potential & Valu & Ided \\
\hline $\begin{array}{l}\text { Farmer } \\
\text { Sugar mill } \\
\text { Distributor }\end{array}$ & 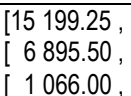 & $\begin{array}{r}59823.00] \\
34198.00] \\
4857.00]\end{array}$ & $\begin{array}{r}{[15.70 \%,} \\
{[35.00 \%,} \\
{[9.18 \%,}\end{array}$ & $\begin{array}{l}23.19 \%] \\
40.75 \%] \\
19.89 \%]\end{array}$ \\
\hline
\end{tabular}

Table 5 Normalized value of uncertain sugarcane supply chain risk and value added

\begin{tabular}{lllll}
\hline $\begin{array}{l}\text { Supply chain } \\
\text { stakeholder }\end{array}$ & $\begin{array}{l}\text { Aggregate risk } \\
\text { potential }\end{array}$ & \multicolumn{2}{l}{ Value added } & \\
\hline Farmer & {$[0.125$,} & $0.490]$ & {$[0.109$,} & $0.161]$ \\
Sugar mill & {$[0.057$,} & $0.280]$ & {$[0.244$,} & $0.284]$ \\
Distributor & {$[0.009$,} & $0.040]$ & {$[0.064$,} & $0.138]$ \\
\hline
\end{tabular}

Tables 4 and 5 illustrate that the highest risk threat bearer borne by farmers, sugar mills, and distributors, respectively. However, they benefit from supply chain value added. This finding indicates an unequal profit allocation in the current situation as shown in Figure 3. Distributors benefit major supply chain profit, though they have low risk threat and low value added contribution. This result shows that fair profit allocation has to be applied in supply chain immediately in consideration of risk and value added.

Therefore, Equations 27-28 may be appropriate for profit allocation solution for all supply chain stakeholders. These equations successfully revised the classic Shapley value result to be fairer and more consistent with supply chain's certain conditions as shown in Figure 3. Fair profit allocation with consideration of risk and value added on sugarcane agro-industrial supply chain is shown in Table 6 and Figure 4.

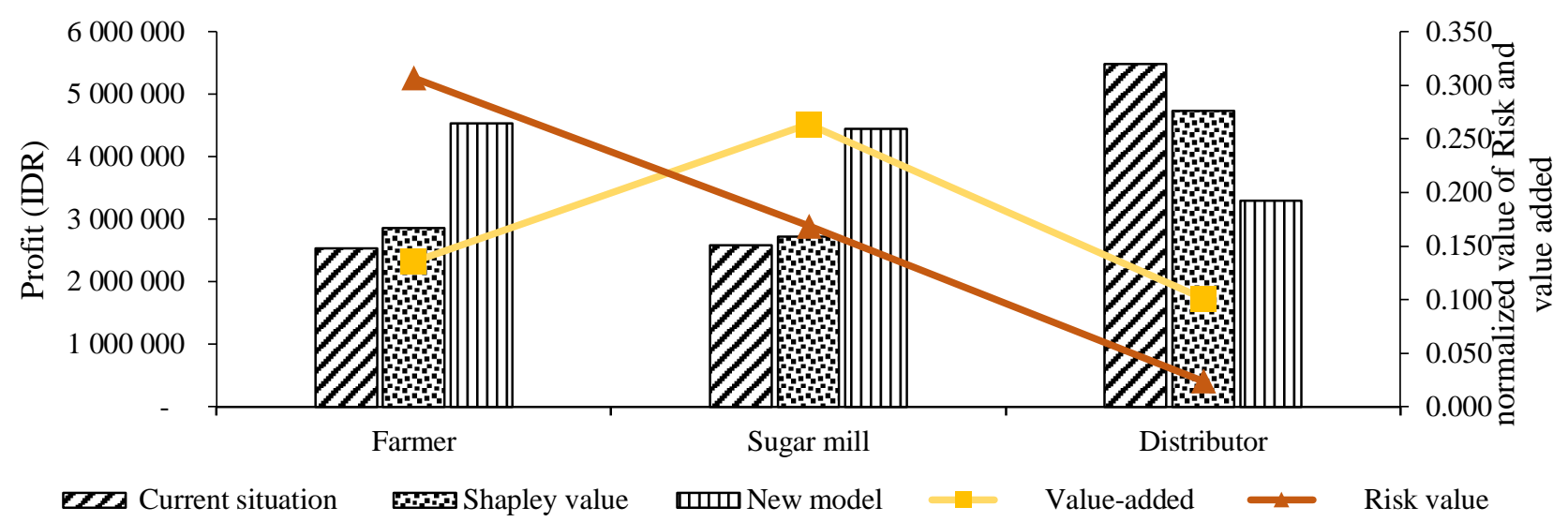

Figure 5 Supply chain profit allocations considering risk and value added

Table 6 Fair profit allocation result considering balanced risk and value added

\begin{tabular}{|c|c|c|c|}
\hline \multirow{2}{*}{$\begin{array}{l}\text { Stakeholder } \\
\text { Farmer }\end{array}$} & \multicolumn{2}{|c|}{ Profit allocation (IDR) } & \multirow{2}{*}{$\begin{array}{l}\text { Comparison (\%) } \\
35.38\end{array}$} \\
\hline & [4 502177.70 , & 9856 763.20] & \\
\hline Sugar-mill & [3 230240.57 , & $8991067.51]$ & 30.11 \\
\hline Distributor & [4 634 517.41, & $9371352.51]$ & 34.51 \\
\hline
\end{tabular}

\section{CONCLUSIONS AND RECOMMENDATIONS}

This paper has successfully established a fair profit allocation model among supply chain stakeholders using cooperative game theory, particularly the Shapley value. The Shapley value is an effective profit allocation model among stakeholders' member of a coalition. However, allocating profit among supply chain stakeholders using the Shapley value needs certain modifications to enhance its appropriateness in supply chain environment. The fuzzy Shapley value is formulated and proven to accommodate uncertain payoff in profit allocation. Furthermore, risk and value added as uncertain factors in supply chain are also considered for fair profit allocation. The fuzzy Shapley value with consideration of a balanced risk and value added on sugarcane supply chain has successfully established a fair profit allocation model. In the case study of the sugarcane agro-industrial supply chain, this paper has shown a fair profit allocation among farmers, sugar mills, and distributors at $35.38 \%, 30.11 \%$, and $34.51 \%$, respectively. This profit allocation is better than previous allocation as found in the current situation in the sugarcane agro-industrial supply chain.

For advanced research, the model could be extended by considering the rate of participation for each stakeholder. Given that stakeholders have another supply chain coalition, their contribution to a coalition would be modeled through fuzzy rate of participation. This research allocates profit among stakeholders based on risk and value added. Future research may consider Return on Investment (ROI) and Return on Assets (ROA in establishing a fair profit allocation model among stakeholders. However, our model could be implemented in other agro-industrial supply chains to confirm a fair profit allocation based on risk and value added.

\section{ACKNOWLEDGMENT}

The research leading to this publication was partly funded by Ministry of Research, Technology and Higher Education, Republic of Indonesia, under special education and research scheme grant: Master leading to Doctor Education program for brilliant undergraduate degree holder (PMDSU-Pendidikan Magister menuju Doktor bagi Sarjana Unggul) batch II fiscal year 2018 and Enhancing International Publication Program (PKPI-Program Peningkatan Publikasi Ilmiah) fiscal year 2018. 


\section{REFERENCES}

Abed-Elmdoust, A. and Kerachian, R. (2012). Water resources allocation using a cooperative game with fuzzy payoffs and fuzzy coalitions. Water Resources Management 26(13), pp. 3961-3976, https://doi.org/10.1007/s11269-012-0115-0.

Alahmari, S. Kamerl, M. and Dahab, M. (2017). An agentbased profit allocation in supply chain management using Shapley value. International Journal of Advance Research in Electronics and Communication Engineering 6(11), pp. 1208-1217.

An, Q. Wen, Y. Ding, T. and Li, Y. (2019). Resource sharing and payoff allocation in a three-stage system: Integrating network DEA with the Shapley value method. Omega 85(2019), pp. 16-25, https://doi.org/10.1016/j.omega.2018.05.008.

Asrol, M. (2018). Mitigasi risiko dan peningkatan nilai tambah pada rantai pasok agroindustri gula tebu [tesis]. Bogor (ID): Institut Pertanian Bogor.

Asrol, M. (2019). Rekayasa model pengambilan keputusan cerdas penyeimbangan risiko dan nilai tambah untuk rantai pasok berkelanjutan agroindustri gula tebu. Institut Pertanian Bogor.

Astuti, R. Marimin Machfud Arkeman, Y. Poerwanto, R. and Meuwissen, M. (2013). Risks and Risks Mitigations in the Supply Chain of Mangosteen: A Case Study. Operations and Supply Chain Management 6(1), pp. $11-25$.

Aumann, R.J. and Myerson, R.B. (1988). Endogenous formation of links between players and of coalitions: an application of the Shapley value. In Roth, A.E. (Ed), The Shapley value: Essays in honor of Lloyd $S$ Shapley, pp. 175-191. Cambridge (UK): Cambridge University Press, https://doi.org/10.1002/pbc.24844.

Ballou, R.H. (2007). The evolution and future of logistics and supply chain management. European Business Review 19(4), pp. 332-348, https://doi.org/10.1108/09555340710760152.

Borkotokey, S. (2008). Cooperative games with fuzzy coalitions and fuzzy characteristic functions. Fuzzy Sets and Systems 159(2), pp. 138-151, https://doi.org/10.1016/j.fss.2007.07.007.

Borkotokey, S. and Mesiar, R. (2014). The Shapley value of cooperative games under fuzzy settings: A survey. International Journal of General Systems 43(1), pp. 75-95, https://doi.org/10.1080/03081079.2013.844695.

BPS. (2016). Distribusi Perdagangan Komoditas Gula Pasir Indonesia 2016. Jakarta (ID): Badan Pusat Statistik.

BPS. (2018). Statistik Tebu Indonesia 2017. Jakarta (ID): Badan Pusat Statistik.

Cachon, G.P. and Netessine, S. (2006). Game Theory in Supply Chain Analysis. In Gray, P. (Ed), Models, Methods, and Applications for Innovative Decision Making October 2018, pp. 200-233. INFORMS, https://doi.org/10.1287/educ.1063.0023.

Cahyani, W.K.D. Marimin, M. and Sukardi, S. (2017). Model produktivitas bagi hasil agroindustri gula tebu dalam kemitraan antara petani dan perusahaan: studi kasus Di PG Kremboong, Sidoarjo. Jurnal Teknologi Industri Pertanian 27(2), pp. 114-124, https://doi.org/10.24961/j.tek.ind.pert.2017.27.2.114.
Castro, J. Gómez, D. Molina, E. and Tejada, J. (2017). Improving polynomial estimation of the Shapley value by stratified random sampling with optimum allocation. Computers and Operations Research 82(2017), pp. 180-188, https://doi.org/10.1016/j.cor.2017.01.019.

Chen, L. Shen, M. and Chen, C. (2010). A research in supply chain profit allocation based on cooperation game theory. Proceedings - 2010 International Conference on System Science, Engineering Design and Manufacturing Informatization, ICSEM 2010 2, pp. 209-212, https://doi.org/10.1109/ICSEM.2010.144.

Chen, W. Zhang, Q. and Wang, M. (2007). Profit allocation scheme among partners in virtual enterprises based on Shapley values with fuzzy payoffs. International Journal of logistics Economics and Globalization 1(1), pp. 49-62.

Chopra, S. and Meindl, P. (2013). Supply Chain Management: Strategy, Planning and Operation. 5th ed. New York (US): Pearson, https://doi.org/10.5772/633.

Chopra, S. and Sodhi, M.S. (2004). Managing risk to avoid supply-chain breakdown. MIT Sloan management review 46, pp. 53-61, https://doi.org/10.1108/IJOPM10-2012-0449.

Deng, L. Wang, R. Dong, T. Feng, J. and Weisong, M. (2016). Assessing the table grape supply chain performance in China - a value chain analysis perspective. British Food Journal 118(5), pp. 11291145, https://doi.org/10.1108/BFJ-09-2015-0310.

deSouza, A. and Haddud, A. (2017). Supply Chain Management Integration in Maintenance and Repair Services Sector. Operations and Supply Chain Management: An International Journal 10(4), pp. 200-213, https://doi.org/10.31387/oscm0290191.

Enyinda, C.I. (2018). Modeling Enterprise Risk Management in Operations and Supply Chain: A Pharmaceutical Firm Context. Operations and Supply Chain Management-an International Journal 11(1), pp. $1-12$.

Fadhil, R. Maarif, M.S. Bantacut, T. and Hermawan, A. (2018). Situational analysis and intervention strategy for Gayo coffee agroindustry institution in Indonesia. Journal of Food, Agriculture and Environment 16(1), pp. 31-40.

Fei, W. Li, D. and Ye, Y. (2018). An approach to computing interval-valued discounted Shapley values for a class of cooperative games under interval data. International Journal of General Systems 47(8), pp. 794-808, https://doi.org/10.1080/03081079.2018.1523903.

Ganesan, K. (2005). On arithmatic operations of interval numbers. International Journal of Uncertainty, Fuzziness and Knowledge-Based Systems 13(6), pp. 619-631.

Gao, J. and Shi, Y. (2010). Research on the profits distribution of the supply chain using shapely value method. In Industrial Engineering and Engineering Management (IE\&EM), $2010 \quad$ IEEE 17Th International Conference on. IEEE, pp. 386-388.

Gao, J. Yang, X. and Liu, D. (2017). Uncertain Shapley value of coalitional game with application to supply chain alliance. Applied Soft Computing Journal 56, pp. 
551-556, https://doi.org/10.1016/j.asoc.2016.06.018.

Gao, J. Zhang, Q. and Shen, P. (2011). Coalitional game with fuzzy payoffs and credibilistic nucleolus. Journal of Intelligent and Fuzzy Systems 8(4), pp. 107-117, https://doi.org/10.3233/IFS-162184.

Gök, S. Branzei, R. and Tijs, S. (2010). The interval Shapley value: an axiomatization. Central European Journal of Operations Research 18(2), pp. 131-140, https://doi.org/10.1007/s10100-009-0096-0.

Hayami, Y. Kawagoe, T. Marooka, Y. and Siregar, M. (1987). Agricultural Marketing and Processing in Upland Java a Perspective From a Sunda Village. Bogor (ID): CGPRT Centre.

Hidayat, S. (2012). Model penyeimbangan nilai tambah berdasarkan tingkat risiko pada rantai pasok minyak sawit [disertasi]. Bogor (ID): Institut Pertanian Bogor.

Hidayat, S. Marimin, M. Suryani, A. Sukardi, S. and Yani, M. (2012). Modifikasi Metode Hayami untuk Perhitungan Nilai Tambah pada Rantai Pasok Agroindustri Kelapa Sawit. Jurnal Teknologi Industri Pertanian 22(1), pp. 22-31.

$\mathrm{Hu}$, B. and Feng, Y. (2017). Optimization and coordination of supply chain with revenue sharing contracts and service requirement under supply and demand uncertainty. International Journal of Production Economics 183(2017), pp. 185-193, https://doi.org/10.1016/j.ijpe.2016.11.002.

Huang, X. Chen, X. and Huang, P. (2018). Research on Fuzzy Cooperative Game Model of Allocation of Pollution Discharge Rights. Water 10(2018), pp. 662673, https://doi.org/10.3390/w10050662.

Hudnurkar, M. Deshpande, S. Rathod, U. and Jakhar, S.K. (2017). Supply Chain Risk Classification Schemes: A Literature Review. Operations and Supply Chain Management 10(4), pp. 182-199.

Jain, S. (2010). Close interval approximation of piecewise quadratic fuzzy numbers for fuzzy fractional program. Iranian Journal of Operation Research 2(1), pp. 7788.

Jian-gang, S. and Guang-dong, W. (2009). Study on the Supply Chain Alliance Profit Allocation Based on Improved Shapley Value. In International Conference on Management Science and Engineering, pp. 507512. Moskow: IEEE.

Kohli, A.S. and Jensen, J.B. (2010). Assessing effectiveness of supply chain collaboration: an empirical study. Supply Chain Forum: An International Journal 11(2), pp. 2-16.

Kumari, P.L. Reddy, G.K. and Krishna, T.G. (2014). Optimum allocation of agricultural land to the vegetable crops under uncertain profits using fuzzy multiobjective linear programming. IOSR Journal of Agriculture and Veterinary Science 7(12), pp. 19-28.

Le, P.H. (2017). Payoff Allocation Methods for Several Operational Research Games [tesis]. Southampton (GB): University of Southampton.

Liu, J. and Sui, C. (2016). A comparative study on the profit distribution model of coal supply chain under inventory financing. Advances in Economics and Management Research 16(2016), pp. 269-274.

Liu, S. and Papageorgiou, L.G. (2018). Fair profit distribution in multi-echelon supply chains via transfer prices. Omega 80(2018), pp. 77-94, https://doi.org/10.1016/j.omega.2017.08.010.

LV, B. and QI, X. (2016). Profit allocation in collaborative product minor updates supply chain enterprises based on improved shapely value. Journal of Advanced Mechanical Design, Systems, and Manufacturing 10(6), pp. 1-11, https://doi.org/10.1299/jamdsm.2016jamdsm0088.

Mares, M. (2001). Fuzzy Cooperative Games: Cooperation with Vague Expectation. Berlin (DE): Springer-Verlag Berlin Heidenberg.

Marimin Umano, M. Hatono, I. and Tamura, H. (1998). Linguistic labels for expressing fuzzy preference relations in fuzzy group decision making. IEEE Transactions on Systems, Man, and Cybernetics, Part B: Cybernetics 28(2), pp. 205-218, https://doi.org/10.1109/3477.662760.

Meng, F. Chen, X. and Tan, C. (2016). Cooperative fuzzy games with interval characteristic functions. Operational Research 16(1), pp. 1-24, https://doi.org/10.1007/s12351-015-0183-z.

Monczka, R.M. Handfield, R. Giunipero, L.C. and Petterson, J.L. (2016). Purchasing and Supply Chain Management Sixth EditionBoston (US): Cengage Learning, 2016.

Muchfirodin, M. Guritno, A.D. and Yuliando, H. (2015). Supply chain risk management on Tobacco commodity in Temanggung, Central Java. Agriculture and Agricultural Science Procedia 3(2015), pp. 235240, https://doi.org/10.1016/j.aaspro.2015.01.046.

Myerson, R.B. (1977). Graphs and cooperation in games. Mathematics of Operations Research 2(3), pp. 225229, https://doi.org/10.1287/moor.2.3.225.

Nishizaki, I. and Sakawa, M. (2000). Fuzzy cooperative games arising from linear production programming problems with fuzzy parameters. Fuzzy Sets and Systems 114(1), pp. 11-21, https://doi.org/10.1016/S0165-0114(98)00134-1.

Nishizaki, I. and Sakawa, M. (2001). Fuzzy and multiobjective games for conflict resolution. Studies in fuzziness and soft computing. Berlin (DE): SpringerVerlag Berlin Heidelberg.

Omri, A. El. (2009). Cooperation in supply chains : alliance formation and profit allocation among independent firms [tesis]. Paris (FR): Ecole Centrale Paris.

Qian, G.X. Zhang, Y.P. Wu, J.G. and Pan, Y.H. (2013). Revenue sharing in dairy industry supply chain - a case study of Hohhot, China. Journal of Integrative Agriculture 12(12), pp. 2300-2309, https://doi.org/10.1016/S2095-3119(13)60585-7.

Ralston, P. (2014). Supply chain collaboration : A literature review and empirical analysis to investigate uncertainty and collaborative benefits in regards to their practical impact on collaboration and performance [disertasi]. Lowa (US): Lowa State University.

Ren, X.Y. Feng, Q.Q. Wang, S. and Wen, X. (2015). Profit distribution of agricultural supply chain based on shapley value. Advance Journal of Food Science and Technology 7(7), pp. 479-483, https://doi.org/10.19026/ajfst.7.1344.

Ricketts, K.D. Turvey, C.G. and Gomez, M.I. (2014). Value 
chain approaches to development. Journal of Agribusiness in Developing and Emerging Economies 4(1), pp. 2-22.

Ronchi, S. Luzzini, D. and Spina, G. (2007). Supply chain coordination: the problem of risk and benefit sharing. Supply Chain Forum: An International Journal 8(2), pp. $54-65$, https://doi.org/10.1080/16258312.2007.11517182.

Sana, S.S. Herrera-Vidal, G. and Acevedo-Chedid, J. (2017). Collaborative model on the agro-industrial supply chain of cocoa. Cybernetics and Systems 48(4), pp. $325-347$, https://doi.org/10.1080/01969722.2017.1285160.

Shapley, L. (1953). A value for n-person games. In Kuhn, H. and Tucker, A. (Eds), Contributions to the Theory of Games II, Annals of Mathematics Studies, pp. 307317. Princeton (US): Princeton University Press.

Starks, D.N. and Bukenya, J.O. (2008). Assessment of the dynamics of value added production in Alabama. In Southern Agriculutural Economics Association Annual Meeting, pp. 2-19. Dallas.

Suharjito, S. and Marimin, M. (2012). Risks balancing model of agri-supply chain using fuzzy risks utility regression. Journal of Theoretical and Applied Information Technology 41(2), pp. 134-144.

Thun, J.-H. (2008). The Potential of Cooperative Game Theory for Supply Chain Management. In Kotzab, H.; Seuring, S.; Muller, M. and Reiner, G. (Eds), Research Methodologies in Supply Chain Management 5, pp. 477-491.

Trienekens, J.H. (2011). Agricultural value chains in developing countries. International Food and Agribusiness Management Review 14(2), pp. 51-82, https://doi.org/103987.html.

Van der Vorst, J. and Snels, J. (2014). Developments and needs for sustainable agro-logistics in developing countries. World Bank Position Note.

Wang, G. Wong, T.N. and Wang, X. (2013). An ontology based approach to organize multi-agent assisted supply chain negotiations. Computers and Industrial Engineering 65(1), pp. 2-15, https://doi.org/10.1016/j.cie.2012.06.018.

Wang, M. Jie, F. and Abareshi, A. (2016). Logistics capability, supply chain uncertainty and risk, and logistics performance: an empirical analysis of the Australian courier industry. Operations and Supply
Chain Management: An International Journal 11(1), pp. 45-54.

Wang, Q. and Parlar, M. (1989). Static game theory models and their applications in management science. European Journal of Operational Research 42(1), pp. 1-21, https://doi.org/10.1016/0377-2217(89)90055-6.

Wang, X. Jiang, L. and Shu, L. (2014). Profit allocation in fuzzy cooperative games in manufacturing and logistics industry. Journal of Industrial Engineering and Management 7(2 SPEC. ISSUE), pp. 448-460, https://doi.org/10.3926/jiem.1030.

Wu, S.Q. (2010). Application of Shapley Value Method in Profits Allocation of Cooperation of Enterprises, Colleges and Institutes. Applied Mechanics and Materials 40-41(2011), pp. 425-429, https://doi.org/10.4028/www.scientific.net/AMM.4041.425.

$\mathrm{Xu}$, W. Yang, Z. and Wang, H. (2014). A Shapley value perspective on profit allocation for RFID technology alliance. 11th International Conference on Service Systems and Service Management, ICSSSM 2014 Proceeding, https://doi.org/10.1109/ICSSSM.2014.6874151.

Xu, Z. Peng, Z. Yang, L. and Chen, X. (2018). An improved shapley value method for a green supply chain income distribution mechanism. International Journal of Environmental Research and Public Health 15(9), pp. 1-18, https://doi.org/10.3390/ijerph15091976.

Yang, H.X. Sun, X. Le Liu, W.M. and Hao, J.Q. (2017). Optimization of profit distribution method under multifactor in construction supply chain. Journal of Interdisciplinary Mathematics 20(6-7), pp. 14351440 , https://doi.org/10.1080/09720502.2017.1382153.

Yao, D.-Q. Yue, X. and Liu, J. (2008). Vertical cost information sharing in a supply chain with valueadding retailers. Omega 36(5), pp. 838-851, https://doi.org/10.1016/j.omega.2006.04.003.

$\mathrm{Yu}, \mathrm{X}$. and Zhang, Q. (2010). An extension of cooperative fuzzy games. Fuzzy Sets and Systems 161(11), pp. 1614-1634, https://doi.org/10.1016/j.fss.2009.08.001.

Zadeh, A. (1965). Fuzzy Sets. Information and control 8, pp. 338-353, https://doi.org/10.1016/S00199958(65)90241-X.

Muhammad Asrol received his PhD and Master degrees at Agro-industrial Technology Department - IPB University by the scheme Master leading to Doctor Education program for brilliant undergraduate degree holder from Indonesian Government supervised by Prof Marimin. On 2018 he also joined Prof Taira laboratory at University of the Rykyus, Japan to finish their current project on Sugarcane Agroindustry. His research interest includes supply chain management, sugarcane agroindustry, decision support system, artificial intelligence and business process modeling. He can be reached at muhammadasrolnaa@gmail.com.

Marimin received the B.S. honor in agro-industrial technology, from Bogor University (Bogor Agricultural University), Bogor, Indonesia, in 1984. In 1990, he received the M.Sc. degree in computer science from the University of Western Ontario, Canada, PhD degree from Faculty of Engineering Science, Osaka University, Japan in 1997. Since 2003, he has been a professor in Systems Engineering with Bogor University. His research interests are intelligent and fuzzy expert systems, intelligent decision support systems, and sustainable supply chain management. Marimin is a member of the Indonesian Engineer Association and as well as Indonesia Logistic and Supply Chain Management and Institute of Electrical and Electronic Engineer (IEEE). He can be reached at marimin@ipb.ac.id. 
Machfud is professor in The Department of Agro-industrial Technology, IPB University - Bogor, Indonesia. He received his Master Degree from Bandung Institute of Technology and Doctoral degree from Bogor Agricultural University. He is past Head of Graduate Study Program of Agro-industrial Technology - IPB University. His research interests include supply chain management, agro-industrial production and management system, lean and green production system, system modelling and optimization.

Moh. Yani is an Associate Professor at IPB University, Indonesia. He received his MEng and Dr Eng from Tokyo Institute of Technology, Japan. He works on environmental chemistry and engineering area such as biofiltration, bioremediation, phytoremediation, and application of oil spill dispersant. He also works on Environmental Technique and Management area such as environmental risk management, HSE, life cycle assessment, and environmental impact assessment. Moh. Yani serves as a Technical Expert at Ministry of Environment and Forestry of Republic of Indonesia. He also serves as a reviewer for many journals.

Eizo Taira is currently a Professor of the Faculty of Agriculture at the University of the Ryukyus, Japan. He received his $\mathrm{Ph} . \mathrm{D}$. from the united school of Agricultural sciences Kagoshima University. His research interest includes development of chemical and physical property for agricultural product using near-infrared spectroscopy, especially in sugarcane. 